\title{
Effect of Bio-Chemical Properties of Various Grains on the Quality Rearing of Factious Host, Sitotroga cerealella (Olivier) and its Subsequent Effect on Trichogramma chilonis in Vitro
}

\author{
Arbab Zubair Ahmad ${ }^{1}$, Farman Ullah ${ }^{1}$, Hayat Badshah ${ }^{2}$, Muhammad Shehzad Khan ${ }^{1 *}$ and Bashir Ahmad ${ }^{1}$
}

${ }^{1}$ Department of Plant Protection, Faculty of Crop Protection Sciences, The University of Agriculture, Peshawar, P.O. Box 25130, Pakistan; ${ }^{2}$ Agricultural Research Institute (ARI), Tarnab, Peshawar-Pakistan.

\begin{abstract}
This study investigated the host preference and development of Sitotroga cerealella as well as its effect on the quality of Trichogramma chilonis under laboratory conditions at Agriculture Research Institute (ARI), Tarnab, Peshawar-Pakistan during, 2017-2018. The cereals (maize, oat, wheat and barley) were evaluated on the basis of total adult emergence, egg laying ability, developmental time of $S$. cerealel$l a$ and enhancing parasitism along with sex ratio of T. chilonis raised on eggs from moths reared on cereals. The response of cereals to $S$. cerealella in no choice test revealed significantly greater adult emergence $(18.9 \pm 12.6)$ and egg laying efficiency $(82.2 \pm 6.8 \mathrm{eggs} /$ female $)$ with shortest developmental time $(27.6 \pm 0.6$ days) in wheat, while adult emergence $(9.62 \pm 6.1)$ was less in maize grains. In choice test, significant effect of developmental time of $S$. cerealella was observed with wheat $(27.4 \pm 0.2$ days $)$ and barley $(27.2 \pm 0.2$ days) allowing short duration. Similarly, T. chilonis preference to eggs of $S$. cerealella adults reared on different cereals showed that percent egg parasitism $(89.6 \pm 1.7,85.2 \pm 2.1)$, percent adult emergence $(95.6 \pm 1.3$, $92.1 \pm 1.4)$ and female sex ratio $(73.1 \pm 0.7,69.6 \pm 1.2)$ of $T$. chilonis was significantly high in moth eggs reared on maize and wheat in no choice conditions respectively. In choice test, sex ratio was significant and maximum females $(70.4 \pm 0.5,77.4 \pm 0.6)$ were observed in eggs from moth reared on wheat and maize. A positive strong correlation of percent adult moth emergence with protein and strong negative between development time and moisture content and carbohydrate was observed. Wheat proved to be suitable as host with high bio-chemical contents for mass rearing of $S$. cerealella that provide maximum moths in short duration and their eggs yield more of T. chilonis, thus recommended for production system of T. chilonis.

Received | August 20, 2019; Accepted | August 04, 2021; Published | October 07, 2021

*Correspondence | Muhammad Shehzad Khan, Department of Plant Protection, Faculty of Crop Protection Sciences, The University of Agriculture, Peshawar, P.O. Box 25130, Pakistan; Email: mskhan_agrarian@yahoo.com

Citation | Ahmad, A.Z., F. Ullah, H. Badshah, M.S. Khan and B. Ahmad. 2021. Effect of bio-chemical properties of various grains on the quality rearing of factious host, Sitotroga cerealella (Olivier) and its subsequent effect on Trichogramma chilonis in vitro. Sarbad Journal of Agriculture, 37(4): 1442-1449.

DOI | https://dx.doi.org/10.17582/journal.sja/2021/37.4.1442.1449

Keywords | Cereals, Egg parasitism, Host preference, No choice test, Protein
\end{abstract}

\section{Introduction}

A ngoumois grain moth, Sitotroga cerealella (Lepidoptera: Gelechiidae), which is an important stored grains pest, is a common host for rearing Trichogramma chilonis. Development of S. cerealella takes place inside the grains, which are directly damaged (Weston and Rattlingourd, 2000).

Cereals, like rice, wheat and corn are suitable for $S$. cerealella; however, their chemical and physical nature, carbohydrate, fat, and protein content is responsible 
for variation in their attraction to insects. $S$. cerealella preference towards cereals varies by changes in nutritive and physical factors of grains (Hamed and Nadeem, 2012). The adult weight, growth period and fecundity of insect progeny are greatly affected by carbohydrate and protein contents of grains (Slansky and Scriber, 1985).

Egg parasitoids, Trichogramma chilonis (Trichogrammatidae) is used worldwide as a bio-control agent that attacks the egg of lepidopterans (Nadeem et al., 2010) depriving them of reaching the larval stage. T. chilonis prefer fresh host eggs and parasitization significantly reduces with time. The adult emergence, longevity and parasitism do not change among different age groups of $S$. cerealella; however, affected along with sex ratio in $T$. chilonis due to temperature and age of eggs (Farid et al., 2001).

Field release technique requires a huge quantity of Trichogramma individuals and therefore, numerous studies are paying attention on the mass rearing and storage of Trichogramma species. T. chilonis use host eggs to complete their life cycle and their sexes have great impact on progeny development and pest control. Since long, wheat is used as a host for rearing $S$. cerealella, but this study sole purpose is to investigate the best possible host that contains balanced bio-chemical compounds and provides large progeny within short duration and also more parasitoids with plenty of female wasps for mass production of T. chilonis. Keeping in view the importance of $S$. cerealella as a host for T. chilonis, the present study is designed for the life cycle parameters of Angoumois grain moth on four cereals to investigate the most preferred cereal and further parasitism rate and sex ratio of T. chilonis with respect to $S$. cerealella reared on cereals.

\section{Materials and Methods}

The common cereals like maize, oat, wheat and barley are frequently found infested by Angoumois grain moth in storages. Therefore, we focused to find a suitable host for the efficient rearing of $S$. cerealella as a host for T. chilonis under laboratory conditions.

\section{Cereals/Seed collection and sterilization of grains}

Seeds of cereal (maize, oat, wheat and barley) weighing one $\mathrm{kg}$ each were bought from local grain market of Peshawar. After washing and sun drying, the grains were put in plastic bags, labeled properly and steri- lized in an autoclave at $121^{\circ} \mathrm{C}$ for 20 minutes, leaving a small portion untreated for chemical analyses.

\section{Culture maintenance of Sitotroga cerealella}

S. cerealella culture was maintained on wheat grains under laboratory at ARI, Tarnab. The collected adults from the rearing chamber in a jar were placed in a plate having starch. After 24 hours, the starch was sieved through 80 mesh sieve obtaining eggs of $S$. cerealella a few of which were kept in wheat jars to maintain the culture, while others particularly single eggs were pasted on hard cards and exposed to T. chilonis to raise its culture for experiments.

\section{Experiment 1: Grain count and chemical analysis}

No. of grains and Infestation level: A $50 \mathrm{~g}$ sample of each cereal was taken from the treated seeds and the number of grains was counted with the help of digital grain counter. The grains were subsequently subjected to infestation by $S$. cerealella to find the number of adults emerged from fixed quantity of grains for three successive generations.

Proximate composition: Chemical analyses of the untreated cereal grains were performed in a laboratory at the Department of Agricultural Chemistry, The University of Agriculture, Peshawar. Overall composition was made using the standard official methods of analysis of AOAC (2016).

Moisture: Oven drying technique was used where each sample $(2 \mathrm{~g})$ was weighed in petri dish $\left(\mathrm{w}_{1}\right.$, primary weight of sample+petri dish) and placed in an oven at $105^{\circ} \mathrm{C}$. After $4-6$ hours, the petri dishes were partly displaced towards desiccators and chilled for 30 minutes. The petri dishes were weighed $\left(\mathrm{w}_{2}\right.$, final weight of sample+petri dish) again and percent moisture content $\left[\left(\mathrm{w}_{1}-\mathrm{w}_{2}\right) /\right.$ weight of sample $\left.\times 100\right]$ was determined.

Ash content: Two grams of each grain sample was placed in a crucible, burned and placed in a muffle furnace for four hours at $550{ }^{\circ} \mathrm{C}$ and then kept in dryers for cooling where their color remained gray white. The crucible was weighed and percent ash (weight of ash/ weight of sample x100) was calculated.

Crude fat: Using Soxhlet's apparatus, each sample (1 g) was folded in ringed filter paper and set in extraction tube. One-third of pre-weighed petroleum ether in a round bottom flask was joined to the extraction 
tube. Later, the solvent was fully dehydrated and shells were detached. The vials were exactly weighed after cooling. Percent crude fat was determined by [(weight of beaker + oil) - (weight of empty beaker)] / weight of sample $\times 100$.

Crude fiber: Acid digestion and alkali method was used for crude fiber. A $200 \mathrm{ml}$ solution containing 2\% $\mathrm{HCl}$ and $2 \mathrm{~g}$ sample in a beaker, was boiled with constant stirring for 30 minutes and then filtered with muslin cloth. Same procedure was repeated replacing $\mathrm{HCl}$ with $\mathrm{NaOH}$. The crucible was weighed and after adding sample, maintained at $105^{\circ} \mathrm{C}$ in an oven for four hours following cooling in desiccators. Sample was again weighed and kept in an oven at $550^{\circ} \mathrm{C}$ for four hours prior to final cooling and weight. Percent crude fiber was found using (Weight of oven dried resdue - weight after ignition)/ sample weight $\times 100$.

Crude protein: Crude protein was observed by Kjeldhal technique. Each sample ( $2 \mathrm{~g})$ was taken in digestion flask with $8 \mathrm{~g}$ K2SO 4 digestion mixture; $\mathrm{CuSO} 4$ (7:1) and $12 \mathrm{ml}$ concentrated $\mathrm{H} 2 \mathrm{SO} 4$ and placed on heater for 30 minutes to get clear color mixture. To make $100 \mathrm{ml}$ volume, distilled water was added to the sample from which $10 \mathrm{ml}$ in funnel was added in distillation tube and to this $10 \mathrm{ml} \mathrm{NaOH}(40 \%)$ was mixed. The distillation remained for ten minutes. In return, $\mathrm{NH} 3$ was obtained as $\mathrm{NH}_{4} \mathrm{OH}$ in conical flask that altered color from pink to yellowish, with indicator modified methyl red and $20 \mathrm{ml}$ of $4 \%$ boric acid solution, which was later titrated against standard $\mathrm{HCl}(0.05 \mathrm{~N})$ till pink color resumed. Percent crude protein was obtained (\% NX 6.25) where N (\%) was also calculated [(Sample reading - Blank reading) $\times$ $\mathrm{NX} \times 0.014 \times$ Sample dilution after digestion] / [ Sample Weight $\times$ Volume for titration] $\times 100$

Crude carbohydrates: Carbohydrate contents were determined by calculating the difference of the sum of percent ash, crude oil and protein as of 100 .

\section{Experiment 2: Host preference tests for S. cerealella}

For both choice and no-choice tests of $S$. cerealella, Vos and Jander (2008) procedure was followed. The tests were replicated five times $(n=5)$.

No choice test: $S$. cerealella were reared on four hosts (maize, oat, wheat and barley) using separate $9 \times 3 \mathrm{~cm}$ plastic jars for which fifty eggs of each host from laboratory culture were examined under microscope for mites infestation and glued on cards prior to infesting grains in jars, enclosed by muslin cloth and maintained in laboratory arena at $27 \pm 2^{\circ} \mathrm{C}$ and $65 \pm 5 \%$ R.H. Moths were allowed to lay eggs on host grains till death.

Choice test: 20 grains of each host (wheat, maize, oat and barley) were placed equidistant in a 14.5 $\mathrm{cm}$ diameter petri dish placing in the center a pair of $S$. cerealella and allowing it to lay eggs freely on its preferred host till death. For adult emergence, the hatched, un-hatched and damaged eggs were counted. The developmental time of $S$. cerealella on each host was recorded for three generations from eggs seeding till first moth emergence. Egg laying efficiency of $S$. cerealella with respect to different hosts in each experiment was determined by enclosing a pair of moth in test tube till death and each of the host grains were examined for eggs through microscope and counted.

\section{Experiment 3: Host reared eggs preference by T. chilonis}

No-choice test: From laboratory culture, 50 eggs of $S$. cerealella reared on each host were glued on $8 \times 3 \mathrm{~cm}$ paper cards and offered to newly emerged $T$. chilonis adults $(20 \pm 4 \mathrm{hrs}$ older) for parasitism in $20 \times 15 \mathrm{~cm}$ separate jars under laboratory conditions at $27 \pm 2^{\circ} \mathrm{C}$ and $65 \pm 5 \%$ R.H.

Choice test: Fresh 30 each host reared eggs of $S$. cerealella were sprinkled inside lines on $3 \times 8 \mathrm{~cm}$ glued hard paper card previously marked and labeled at equal distance for hosts. On drying, the card was exposed to T. chilonis pair for $24 \mathrm{hrs}$ in a jar. After parasitism, these cards were placed in separate jars under same laboratory conditions.

For tests, percent sex ratio and percent adult emergence was noted by counting, while percent parasitism was recorded by given formula:

Parasitism $(\%)=\frac{\text { No. of parasitized eggs }}{\text { Total No. of eggs offered }} \times 100$

\section{Statistical analysis}

Data on host preference by $S$. cerealella and T. chilonis were subjected to analysis of variance through completely randomized design. Means were separated by Fischer's protected least significance difference test at 5\% probability level. All statistical tests were done using Statistix 8.1 and figures were structured by SigmaPlot 8.0 software. 

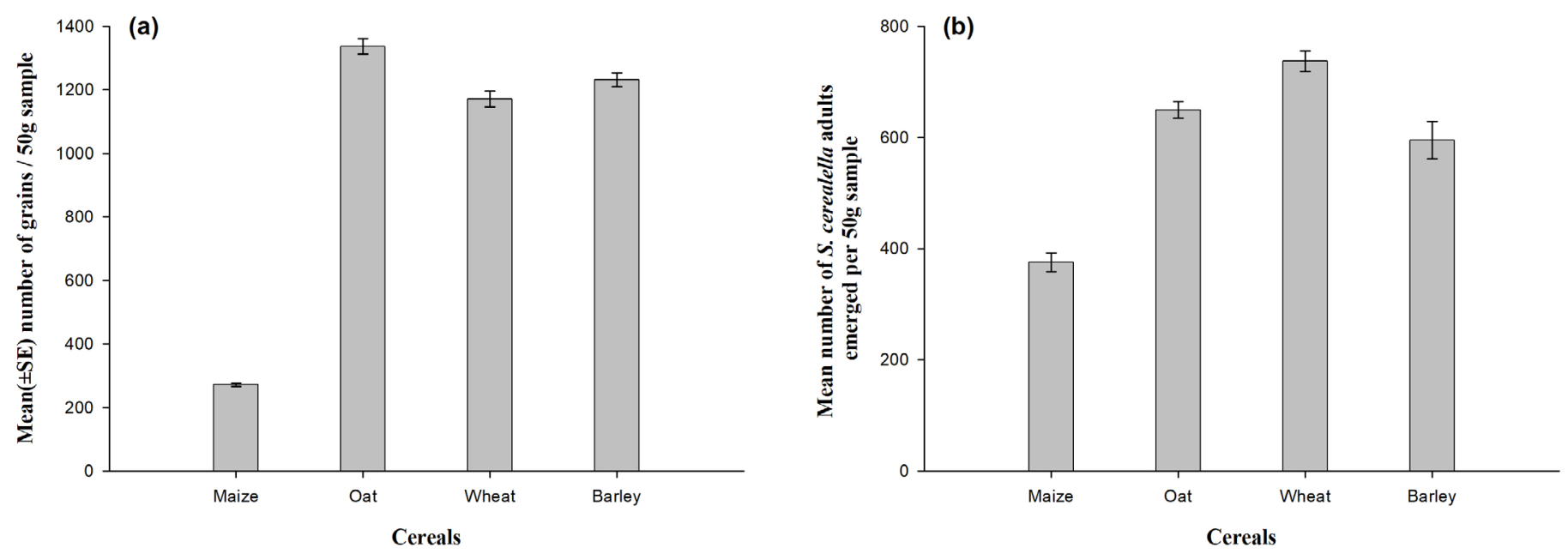

Figure 1: Mean ( $\pm S E$ ) number of (a) grains and (b) adults emerged per 50 grams sample of different selected cereals.

Table 1: Chemical analysis of different cereal grains for percentage moisture, protein, fat, fiber, ash and carbohydrate contents.

$\begin{array}{lllllll}\text { Cereals } & \text { \%Mean } \pm \text { SE } & & & & \\ & \text { Moisture } & \text { Protein } & \text { Fat } & \text { Fiber } & \text { Ash } & \text { Carbohydrate } \\ \text { Maize } & 13.2 \pm 0.21 \mathrm{a} & 8.7 \pm 0.20 \mathrm{c} & 3.7 \pm 0.32 \mathrm{~b} & 1.9 \pm 0.11 \mathrm{c} & 1.3 \pm 0.08 \mathrm{~b} & 70.4 \pm 0.36 \mathrm{~b} \\ \text { Oat } & 8.10 \pm 0.11 \mathrm{~d} & 13.0 \pm 0.25 \mathrm{a} & 7.3 \pm 0.11 \mathrm{a} & 5.0 \pm 0.14 \mathrm{a} & 1.9 \pm 0.08 \mathrm{a} & 64.6 \pm 0.20 \mathrm{c} \\ \text { Wheat } & 12.3 \pm 0.13 \mathrm{~b} & 12.1 \pm 0.15 \mathrm{~b} & 2.0 \pm 0.15 \mathrm{c} & 2.1 \pm 0.03 \mathrm{bc} & 2.0 \pm 0.05 \mathrm{a} & 69.6 \pm 0.46 \mathrm{~b} \\ \text { Barley } & 11.2 \pm 0.12 \mathrm{c} & 9.2 \pm 0.08 \mathrm{c} & 2.2 \pm 0.17 \mathrm{c} & 2.4 \pm 0.05 \mathrm{~b} & 2.0 \pm 0.15 \mathrm{a} & 72.9 \pm 0.19 \mathrm{a} \\ \text { LSD } & 0.4982 & 0.6003 & 0.6810 & 0.3216 & 0.3351 & 0.9818\end{array}$

Means in columns followed by same letters are not significantly different at 5\% level of probability using Fischer's Protected LSD test.

\section{Results and Discussion}

\section{Number of grains and Infestation level}

Results showed that number of grains varied significantly $\left(F_{3,16}=581 ; P<0.001\right)$ among the cereals (Figure 1a). Maize had significantly lowest mean number of grains in $50 \mathrm{~g}$ sample followed by wheat and barley, while highest number of grains was recorded in oat. Further, infestation level of grains (Figure $1 \mathrm{~b}$ ) revealed that a significantly $\left(F_{3,16}=48.3 ; P<0.001\right)$ highest mean number of $S$. cerealella adults emerged in wheat grains in three successive generations irrespective of grain size. This indicated that small number of grains irrespective of size can facilitate only few insects and consequently leads to poor rearing technique.

\section{Chemical analysis}

Results revealed a highly significant but inconsistent variation among the proximate chemical analysis of cereal types. The moisture content was highly significant $\left(F_{3,8}=216 ; P<0.001\right)$ in maize followed by wheat as compared to other cereals (Table 1). Protein content was highly significant $\left(F_{3,8}=130 ; P<0.001\right)$ in oat followed by wheat, whereas, fat content was found significantly higher $\left(F_{3,8}=138 ; P<0.001\right)$ in oat and lower in wheat grains. Crude fiber was found significantly maximum $\left(F_{3,8}=224 ; P<0.001\right)$ in oat and minimum in maize. A highly significant $\left(F_{3,8}=8.56\right.$; $P=0.007)$ ash content was observed in both oat and barley. Carbohydrate content was highly significant $\left(F_{3,8}=122 ; P<0.001\right)$ in barley and less amount observed in oat.

\section{Host preference by S. cerealella}

Innochoicetest,mothemergence $\left(F_{3,16}=25.7 ; P<0.001\right)$, egglaying efficiencyof S. cerealella $\left(F_{3,16}=3.58 ; P=0.038\right)$ and developmental time $\left(F_{3,16}=16.6 ; \quad P<0.001\right)$ showed significant variations. Maximum adult emergence was observed in wheat and minimum in maize, while egg laying efficiency was higher in wheat $(\mathrm{Ta}-$ ble 2). A longer developmental time by moths was noted on oat and shortest on wheat (Figure 2a).

In choice test (Table 2), non-significant differences were observed among the cereals in emergence of moths $\left(F_{3,16}=1.86 ; P=0.143\right)$ and their egg laying efficiency $\left(F_{3,16}=1.46 ; P=0.262\right)$; however, developmental time was highly significant $\left(F_{3,16}=38.9 ; P<0.001\right)$ where maximum time was observed on oat and maize (Figure 2b). 
(a)

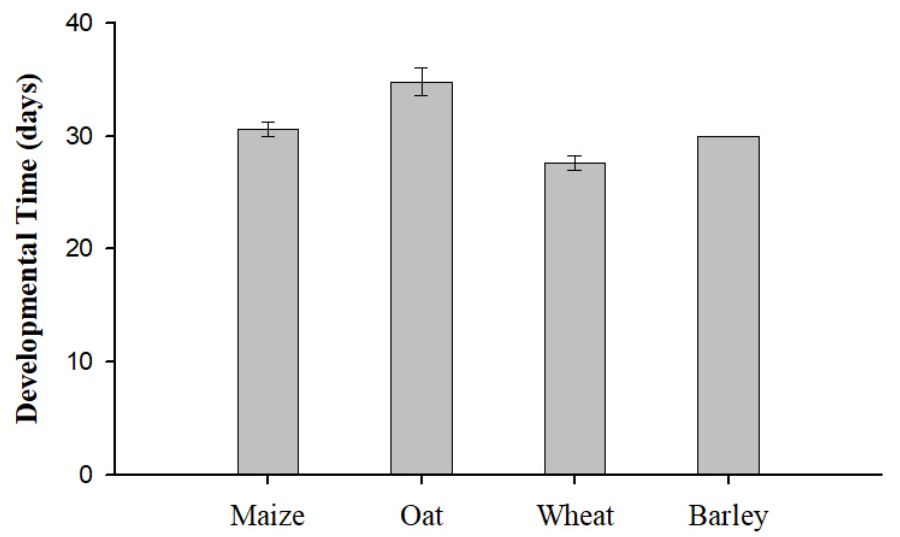

(b)

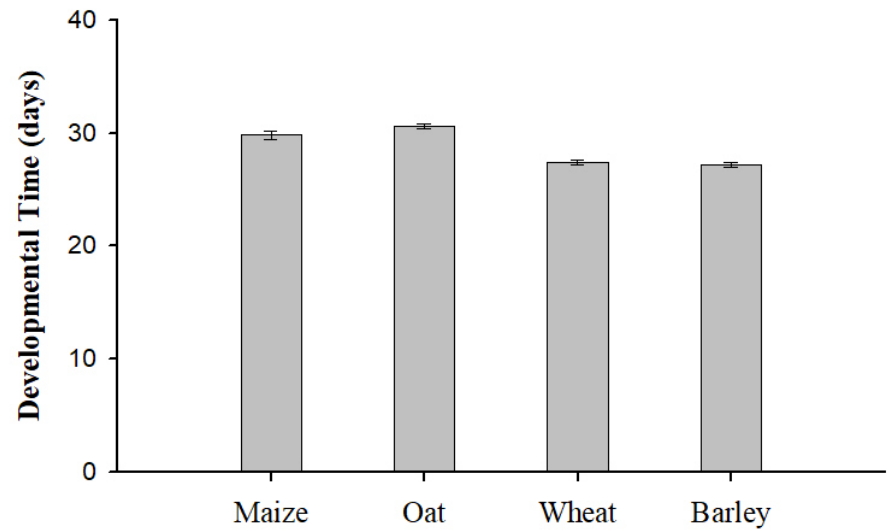

Figure 2: Mean ( $\pm S E$ ) developmental time (days) of S. cerealella on selected cereal grains in (a) no choice test and (b) choice test under controlled laboratory conditions at ARI, Tarnab, Peshawar.

Table 2: Host preference of $S$. cerealella to selected cereal grains for adult emergence and its egg laying efficiency in no choice and choice tests at ARI, Tarnab, Peshawar.

\begin{tabular}{|c|c|c|c|c|}
\hline \multicolumn{5}{|c|}{ Cereals Mean \pm SE } \\
\hline & \multicolumn{2}{|l|}{ No choice test } & \multicolumn{2}{|c|}{ Choice test } \\
\hline & $\begin{array}{l}\text { Adult emer- } \\
\text { gence }\end{array}$ & $\begin{array}{l}\text { Egg laying } \\
\text { efficiency }\end{array}$ & $\begin{array}{l}\text { Adult } \\
\text { emergence }\end{array}$ & $\begin{array}{l}\text { Egg laying } \\
\text { efficiency }\end{array}$ \\
\hline Maize & $9.62 \pm 6.08 c$ & $53.8 \pm 10.50 \mathrm{~b}$ & $25.2 \pm 1.78$ & $94.2 \pm 4.27$ \\
\hline Oat & $16.6 \pm 12.40 \mathrm{~b}$ & $42.6 \pm 5.60 \mathrm{~b}$ & $23.1 \pm 1.46$ & $80.2 \pm 7.80$ \\
\hline Wheat & $18.9 \pm 12.60 \mathrm{a}$ & $82.2 \pm 6.80 \mathrm{a}$ & $28.1 \pm 1.87$ & $96.4 \pm 3.98$ \\
\hline Barley & $15.2 \pm 11.00 \mathrm{~b}$ & $64.4 \pm 11.20 \mathrm{ab}$ & $23.4 \pm 1.57$ & $84.8 \pm 8.12$ \\
\hline LSD & 2.167 & 26.702 & NS & NS \\
\hline
\end{tabular}

Means in columns followed by same letters are not significantly different (NS) at 5\% level of probability using Fischer's Protected LSD test.

\section{Host preference by T. chilonis}

Under no choice test, there were highly significant differences among cereals for percent egg parasitism $\left(F_{3,16}=5.63 ; P=0.008\right)$ and percent adult emergence $\left(F_{3,16}=19.5 ; P<0.001\right)$ of $T$. chilonis on moth eggs. Highest percent egg parasitism by $T$. chilonis and their percent adult emergence were recorded in eggs of $S$. cerealella reared on maize and wheat in both variables, while lowest on oat and with the addition of barley in adult emergence (Table 3). The percent male to female ratio of $T$. chilonis was significantly affected by $S$. cerealella eggs reared on cereals. A highly significant difference was observed in $T$. chilonis percent males $\left(F_{3,16}=163 ; P<0.001\right)$ and females $\left(F_{3,16}=122 ; P<0.001\right)$ where maximum percent males were produced in oat and females in wheat grains (Figure 3a).

Results of choice test gave non-significant differences among cereals for percent egg parasitism $\left(F_{3,16}=2.71\right.$; $P=0.079)$ and adult emergence $\left(F_{3,16}=1.42 ; P=0.273\right)$ of $T$. chilonis (Table 3); however, their sex ratio was significant for $T$. chilonis percent males $\left(F_{3,16}=305\right.$; $P<0.001)$ and females $\left(F_{3,16}=304 ; P<0.001\right)$ with higher number of males and females emerged from $S$. cerealella eggs reared on oat and wheat respectively (Figure 3b).

Table 3: T. chilonis percent parasitization of S. cerealella eggs and percent adult emergence in no choice and choice tests at ARI, Tarnab, Peshawar.

\begin{tabular}{lllll} 
Cereals & \multicolumn{2}{l}{ Mean \pm SE } & & \\
& \multicolumn{2}{l}{$\begin{array}{l}\text { No choice test } \\
\text { \%Egg para- }\end{array}$} & \%Adult & \multicolumn{2}{l}{ \%Egoice test } \\
& $\begin{array}{l}\text { \% Egg para- } \\
\text { sitism }\end{array}$ & emergence & sitism & emergence \\
Maize & $85.2 \pm 2.05 \mathrm{ab}$ & $95.56 \pm 1.34 \mathrm{a}$ & $89.96 \pm 2.35$ & $91.87 \pm 0.57$ \\
Oat & $79.2 \pm 1.74 \mathrm{c}$ & $84.24 \pm 1.12 \mathrm{~b}$ & $86.62 \pm 2.77$ & $88.49 \pm 2.04$ \\
Wheat & $89.6 \pm 1.72 \mathrm{a}$ & $92.06 \pm 1.43 \mathrm{a}$ & $92.62 \pm 1.93$ & $90.81 \pm 1.31$ \\
Barley & $83.2 \pm 1.74 \mathrm{bc}$ & $85.96 \pm 0.76 \mathrm{~b}$ & $94.62 \pm 0.80$ & $92.22 \pm 1.31$ \\
LSD & 5.463 & 3.583 & NS & NS
\end{tabular}

Means in columns followed by same letters are not significantly different (NS) at 5\% level of probability using Fischer's Protected LSD test.

\section{Correlation}

Relationship of the life parameters of $S$. cerealella with others variables was determined (Table 4). The correlation of adult emergence under no choice test with number of grains and proteins was strong positive and with ash was positive and significant, whereas, all other correlations were non-significant. Similarly, with high significance the number of grains was positively correlated to protein and ash and negatively to moisture content; however, with fiber was positive and significant, while all other correlations were expressed as non-significant. 
(a)

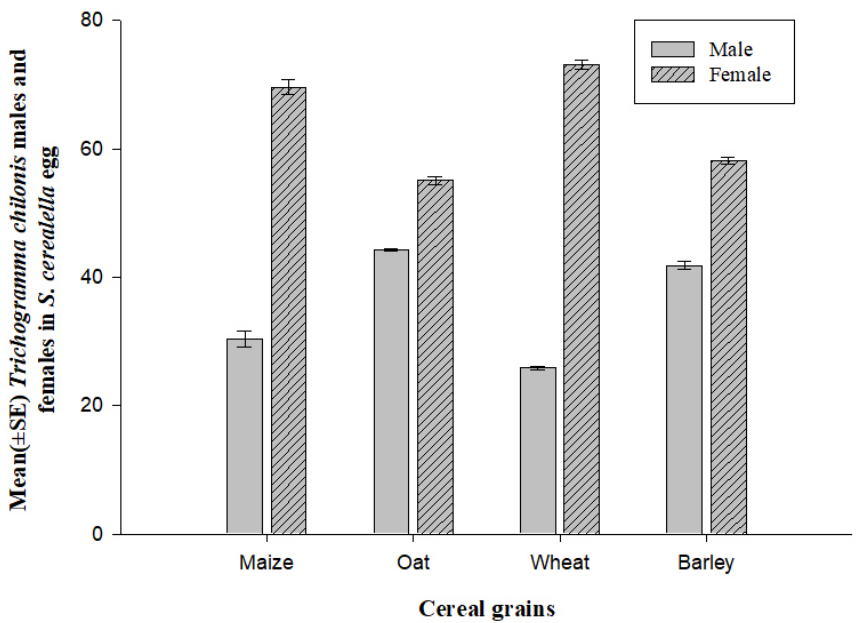

(b)

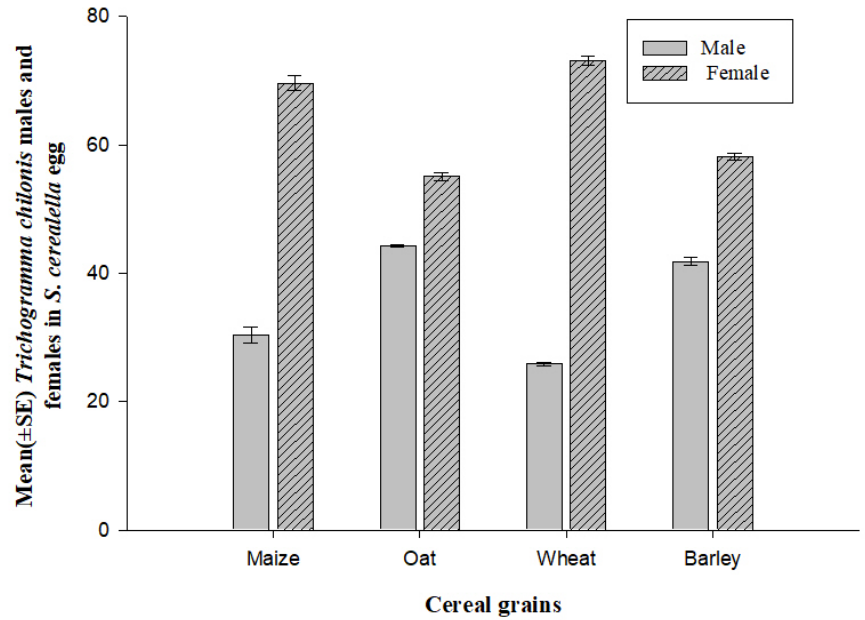

Figure 3: Mean ( $\pm S E$ ) percent male and female T. chilonis developed in eggs of $S$. cerealella reared on selected cereal grains in (a) no choice test and (b) choice rest under controlled laboratory conditions at ARI, Tarnab, Peshawar.

Table 4: Correlation coefficients ( $r$ ) of some biological parameters of Sitotroga cerealella fed on different cereals with chemical compositions of the grains.

$\begin{array}{llllllll}\text { Biological Parameters } & \text { No. of grains } & \text { Moisture } & \text { Protein } & \text { Fat } & \text { Fiber } & \text { Ash } & \text { Carbohydrate } \\ \text { Adult emergence } & 0.8301^{* *} & -0.3966 & 0.7205^{* * *} & -0.0160 & 0.3014 & 0.4766^{*} & -0.2359 \\ \text { Egg-laying efficiency } & 0.0845 & 0.4094 & -0.0218 & -0.5197^{*} & -0.4377 & -0.0550 & 0.4307 \\ \text { Development time } & 0.1442 & -0.6744^{* *} & 0.2846 & 0.8517^{* *} & 0.7514^{* *} & 0.0750 & -0.6492^{* *}\end{array}$

Means in columns followed by same letters are not significantly different (NS) at $5 \%$ level of probability. ** Highly significant, * Significant.

The correlation of egg laying efficiency was only significant with crude fat with positive impact. The developmental time in correlation with moisture and carbohydrate was strong negative and strong positive with crude fiber and crude fat, though non-significant with ash and protein.

This study investigated the host preference and development of Sitotroga cerealella on different cereals and their detailed effect on the quality of $T$. chilonis under laboratory conditions. Studies on different parameters have already been conducted in comparing the effects of different cereal types and even their different strains and on finding emergence, development time and fecundity of $S$. cerealella (Rizwana et al., 2011; Hamed and Nadeem, 2012; Borzoui et al., 2017; Safian Murad and Batool, 2017) that are attributed to varying nutritional values as well as physical and chemical nature of cereals (Khan et al., 2010; Mahmoud et al., 2020). While rearing $S$. cerealella on wheat as compared to maize and other cereal grains in present study, larger numbers of eggs were obtained and this is consistent with findings by Mahmoud et al. (2020).

Under no choice conditions, our study indicated that significantly shortest developmental period was recorded in wheat indicating its regular use for the insect as development occurs in shortest achievable time. These results are in line with the findings of Hamed and Nadeem (2012) proposing shortest developmental time on wheat and barley. Development time strong negatively correlated to the moisture content and carbohydrates of grains and this has previously been recognized by Demissie et al. (2015) indicating a decrease in development time with increased moisture and carbohydrate contents of grains. Percent adult emergence of $S$. cerealella was highest on wheat and lowest on barley in our findings and the cause might be several factors; however, this was in agreement with the evidences provided by Hamed and $\mathrm{Na}-$ deem (2012) and Shah et al. (2015) where a higher adult emergence of $S$. cerealella on wheat was recorded. Likewise, Soomro et al. (2017) revealed maximum adult emergence of Angoumois grain moth on wheat as compare to other cereals. On the other hand, $S$. cerealella adult emergence has strong positive correlation with the protein content of grains and this is similar to the results of Ignjatovic et al. (2018). Ash content of grains also helps in the emergence of $S$. cerealella adults (Demissie et al., 2015; Ignjatovic et al., 2018). Moreover, egg laying efficiency of $S$. cere- 
alella reared on wheat was highest and lowest on oat. These results are supported by Hamed and Nadeem (2012) indicating maximum egg laying by $S$. cerealella females emerged on wheat and barley than on maize and oat.

In our study, results of choice test indicated an extended developmental period of $S$. cerealella on oat and maize, while shorter on wheat and barley, which is in line with the research work of Hamed and Nadeem (2012) identifying a prolonged developmental time on oat and maize. Variations in the susceptibility of cereals to insect were due to their chemical and physical nature of grains attributed by fat, carbohydrate, protein and moisture content as well as hardness of the grains (Khan et al., 2010; Ignjatovic et al., 2018; Mahmoud et al., 2020). Further, egg laying efficiency of $S$. cerealella was high when reared on wheat and low on oat. Similar results have been defined by Hamed and Nadeem (2012) that Sitotroga cerealella when reared on barley and wheat than maize and oat laid more eggs. Cereal grains resistance to storage insects may be due to oviposition preference for grains, egg hatch, insect progeny and grain weight loss (Shafique and Ahmad, 2003). In our research, maximum adult emergence was found in wheat grains.

Study of host preference by T. chilonis under no choice condition proposed that percent egg parasitism, and percent adult emergence was observed maximum on eggs from $S$. cerealella reared on maize and wheat, This is at par with results of Hamed and Nadeem (2012) where maximum egg parasitism and adult emergence of T. chilonis on maize host eggs was noted. Likewise, Shah et al. (2015) reported that T. chilonis egg parasitism and adult emergence was maximum on maize host eggs. The host value can influence developmental time, longevity, parasitism and adult emergence (Greenberg et al., 1998). Further, T. chilonis percent males were recorded maximum and minimum on oat and wheat respectively, while percent females were highest in wheat and lowest in oat. It has been documented that $T$. chilonis adjusts its sex ratio with change in nature and size of host eggs (Hamed and Nadeem, 2012).

\section{Conclusions and Recommendations}

Wheat and maize both can develop maximum $S$. cerealella adults in short duration but the moisture and protein contents of wheat are high enough that meet the requirements of $S$. cerealella. Though, T. chilonis wasps prefer to parasitize large and fresh eggs so apparently good and strong $S$. cerealella adults should be selected for egg masses and subsequent rearing of T. chilonis. Furthermore, eggs from $S$. cerealella reared on wheat and maize grains should be exposed to $T$. chilonis as they can produce more females. However, number of seeds per gram of maize is much less than wheat and further, developmental time of $S$. cerealella in maize is greater than in wheat, yielding less number of hosts and eggs for parasitoid. More number of seeds rich in protein, ash and carbohydrate with high moisture contents inflicting higher number of $S$. cerealella emergence with shortest duration of development that favors maximum number of female T. chilonis, ultimately will parasitize more host eggs; therefore, wheat is recommended as a perfect cereal for $S$. cerealella and subsequent mass rearing of $T$. chilonis.

\section{Novelty Statement}

This study concentrated on finding the most suitable host for $S$. cerealella, which could in turn produce enormous T. chilonis. Additionally, this research evidenced wheat among four cereals a better host containing ideal level of protein, carbohydrate, ash and moisture contents that provides shortest development time with maximum adults' emergence and egg laying efficiency of $S$. cerealella, which is a confirmation that large progeny will be provided within short duration for mass production of T. chilonis. Further, investigating T. chilonis female to male ratio is advancement as more female progeny is required in biological control approaches.

\section{Author's Contribution}

Arbab Zubair Ahmad: Conducted this research study and outlined this paper.

Farman Ullah: Planned and supervised this research. Hayat Badshah and Muhammad Shehzad Khan: Analyzed data and helped in results interpretation.

Bashir Ahmad and Muhammad Shehzad Khan: Facilitated in technical writing and reviewed the manuscript.

All authors read and approved the final manuscript.

\section{Conflict of interest}

The authors have declared no conflict of interest. 


\section{References}

Association of Official Analytical Chemists. 2016. Official Methods of Analysis of AOAC International. $20^{\text {th }}$ edn. AOAC International, Maryland, USA.

Borzoui, E., B. Naseri and G. Nouri-Ganbalani. 2017. Effects of food quality on biology and physiological traits of Sitotroga cerealella (Lepidoptera: Gelechiidae). J. Econ. Entomol. 110(1): 266-273.

Demissie, G., R. Swaminathan, O.P. Ameta, H.K. Jain and V. Saharan. 2015. Biochemical basis of resistance in different varieties of maize for their relative susceptibility to Sitotroga cerealella (Olivier) (Lepidoptera: Gelechiidae). J. Stored Prod. Postharv. Res. 6(1): 1-12.

Farid, A., T. Saqib and A.U. Khan. 2001. Host age effect on oviposition preference and development of Trichogramma chilonis. Pak. J. Biol. Sci. 4(2): 121-122.

Greenberg, S.M., R.K. Morrison and D.A. Nordlund. 1998. A review of the scientific literature and methods for production of factitious hosts for use in mass rearing of Trichogramma spp. (Hymenoptera: Trichogrammatidae) in the former Soviet Union, the United States, Western Europe and China. J. Entomol. Sci. 33(1): 15-32.

Hamed, M. and S. Nadeem. 2012. Effect of cereals on the development of Sitotroga cerealella (Olivier) (Lepidoptera: Gelechiidae) and subsequent quality of the egg parasitoid, Trichogramma chilonis (I.) (Hymenoptera: Trichogrammatidae). Pak. J. Zool. 44(4): 923-929.

Ignjatovic, C.A., P. Kljajic, G. Andric, M.P. Golic, M. Kavran and D. Petric. 2018. Behaviour of the Angoumois grain moth (Sitotroga cerealella Oliver) in different grain substrates and assessment of losses. Proceedings of the $12^{\text {th }}$ International Working Conference on Stored Product Protection (IWCSPP) in Berlin, Germany., October 7-11, 2018. Julius Kuhn Archiv, 463: 193-203.

Khan, I., S. Afsheen, N. Din, S.U.K. Khattak, S.K. Khalil, Y. Hayat and L. Lou. 2010. Appraisal of different wheat genotypes against Angoumois grain moth, Sitotroga cerealella (Olivier). Pak. J. Zool. 42: 161-168.

Mahmoud, H.H., A.G.T. Abd-El Sater, D.S. Mohammed and M.M. Sadek. 2020. Egg produc- tion and life cycle of Sitotroga cerealella (Lepidoptera: Gelechiidae) reared on three cereals. Egypt. J. Plant Prot. Res. Inst. 3(1): 58-72.

Nadeem, S., M. Ashfaq, M. Hamed and S. Ahmed. 2010. Optimization of short and long term storage duration for Trichogramma chilonis (Ishii) (Hymenoptera: Trichogrammatidae) at low temperatures. Pak. J. Zool. 42(1): 63-67.

Rizwana, S., M. Hamed, A. Naheed and S. Afghan. 2011. Resistance in stored rice varieties against Angoumois grain moth, Sitotroga cerealella (O1ivier) (Lepidoptera: Gelechiidae). Pak. J. Zool. 43: 343-348.

Safian Murad, M. and Z. Batool. 2017. Relative biochemical basis of susceptibility in commercial wheat varieties against Angoumois grain moth, Sitotroga cerealella (Olivier) and construction of its life table. J. Biom. Biostat. 8(1): 333, 1-7. https://doi.org/10.4172/2155-6180.1000333

Shafique, M. and M. Ahmad. 2003. Susceptibility of milled rice genotypes to Angoumois grain moth, Sitotroga cerealella (Oliver) (Lepidoptera: Gelechiidae). SAARC J. Agric. 1: 193-197.

Shah, M.S., I.A. Khan, M. Salman, J. Ahmad, I. Akbar, J. A. Shah, G. Z. Khan and M. Sarwar. 2015. Study on different life parameters of Trichogramma chilonis on eggs of Sitotroga cerealella (Olivier) fed on old and new varieties of wheat, maize and sorghum. J. Entomol. Zool. Stud. 3(6): 397-400.

Slansky, F.Jr. and M.J. Scriber. 1985. Food consumption and utilization. In: Kerkut, G.A. and L. I. Gilbert (eds.). Comprehensive insect physiology, biochemistry and pharmacology. Vol. 4. Pergamon Press, Oxford, U.K. Pp. 87-163.

Soomro, A.A., M. Hussain, F.H. Magsi, K. Khanzada, S.M. Jaffery, M.A. Chandio and B.H. Chang. 2017. Population dynamics of Angoumois grain moth, Sitotroga cerealella (Olivier) on cereals at room temperature. Int. J. Fauna Biol. Stud. 4(4): 187-191.

Vos, D.M. and G. Jander. 2008. Choice and nochoice assays for testing the resistance of $A$. thaliana to chewing insects. J. Vis. Exp. (15): e683.

Weston, P.A. and P.L. Rattlingourd. 2000. Progeny production by Tribolium casteneum and Oryzaephilus surinamensis in maize previously infested by Sitotroga cerealella. J. Econ. Entomol. 93(2): 533-536. 